\title{
A oralidade incorporada à narrativa contemporânea de Moçambique
}

\author{
Daniela de Brito*
}

Resumo

\begin{abstract}
Atentando para o entrelaçamento de procedimentos orais e escritos, este artigo tem por objetivo percorrer duas manifestações ficcionais da literatura moçambicana contemporânea, os romances O sétimo juramento (2000), de Paulina Chiziane, e Neighbours (2004), de Lília Momplé,privilegiando a análise do modo como a performance dos contadores de história é encenada e qual a funcionalidade dessa representação, seja estabelecendo uma comparação entre elas, seja em uma perspectiva individualizada. Lembrando que o corpus escolhido, embora apresente muitas semelhanças, uma vez que todo trabalho que visa aproximar romances de autores diferentes tende a partir de um ponto comum, contém especificidades que serão levadas em consideração.
\end{abstract}

Palavras-Chave: Oralidade. Escrita. Romances. Contador de histórias. Moçambique.

\section{Orality Incorporated Into The Contemporary Narrative Of Mozambique}

\begin{abstract}
Paying attention to the oral and written procedures interlace, this article aims to go two fictional manifestations of the Mozambican contemporary literature the novels O sétimo juramento (2000), of Paulina Chiziane, and Neighbours (2004), of Lilian Momplé, privileging the analysis of how the performance of Storytellers is performed and what the functionality of this representation, is establishing a comparison between them, whether in an individual perspective. Remembering that the corpus chosen, although many similarities, since all the work which aims to approach diferente authors novels tends to from a common, contains special features which will be taken into consideration.
\end{abstract}

Keywords: Speaking. Writing. Novels. Storyteller. Mozambique

Recebido: 29/01/2019

Aceito: $12 / 04 / 2019$

\footnotetext{
* Universidade Estadual Paulista "Júlio de Mesquita Filho" (Unesp). É doutora em Letras, na área de concentração de Literaturas em Língua Portuguesa.
} 
Em Moçambique, a Literatura, até a década de 1990, como explica Chaball (1994, p. 65), embora fosse despojada da tradição de prosa "moderna", indicava que esta era uma área em expansão, pois, no período colonial, a poesia predominava por ser um meio de burlar a censura, enquanto a prosa era um instrumento perigoso para ser utilizado no contexto da repressão política. Além disso, não havia tradição de prosa africana em língua portuguesa ou mesmo em línguas africanas; aliás, levando em consideração a situação da educação da colônia, o número de africanos letrados era pequeno para alimentar uma literatura de língua portuguesa com raízes na cultura oral.

Todavia esse quadro começa a mudar durante a luta pela libertação do país, com a publicação de algumas obras significativas, como Godido e outros contos, de João Dias, em 1950; Nós matamos o cão tinhoso, de Luís Bernardo Honwana, em 1964; e Portagem, de Orlando Mendes, de 1966, considerado por alguns críticos o primeiro romance moçambicano. Essas narrativas apontam a colonização opressora, assinalando as circunstâncias em que vivem os colonizados. Porém, no período situado entre 1975 e 1992, denominado “Consolidação", por Pires Laranjeira (1995, p. 262), a ficção moçambicana adquire, definitivamente, autonomia e extensão inquestionáveis. Nesse período pósindependência, despontam nomes, como o de Mia Couto, no livro Vozes Anoitecidas, em 1983, além dos autores que compõem a revista Charrua, editada a partir de 1984, como Ungulani Ba Ka Khosa, Pedro Chissano, Hélder Muteia, inaugurando novos caminhos, novas possibilidades para a criação literária.

Convém ressaltar que os autores, até aqui, de um modo geral, dão preferência ao conto que, utilizando-nos dos termos de Ana Mafalda Leite (2003, p. 90), “[...] se adapta e se revela como a prática narrativa mais adequada, tendo em conta os seus estreitos laços com a oralidade, [...]". ${ }^{1}$ Contudo, a partir de 1990, o romance também passa a ser praticado com frequência por Mia Couto, Paulina Chiziane, Suleiman Cassamo, Lília Momplé, João Paulo Borges Coelho, Ungulani Ba Ka Khosa, ${ }^{2}$ entre outros, que recorrem ao registro de modelos orais em suas práticas narrativas, tentando repor na escrita, como assinalam as palavras de Leite (2003, p. 92), a arte do griot, do contador de histórias, em que os narradores "[...] vem contar a forma como se conta, na sua terra, encenando as estratégias narrativas, em simultâneo à narração". Ou seja, é possível perceber, na ficção contemporânea de Moçambique, a incorporação de elementos da oralidade pela escrita, o que condiz com uma estratégia discursiva pós-colonial persistente e causadora de uma hibridez que, por sua vez, servindo-nos do que diz Mata (2003, p. 67), "[...] é uma das marcas das culturas pós-coloniais [...], resultado de uma situação de semiose cultural ou de relação dialética entre matrizes civilizacionais diversas [...]”.

Essa relação de confluência de dicotomias pode ser vista, por exemplo, nos romances que compõem o corpus deste trabalho, em que se evidencia uma tentativa de amalgamar elementos do legado oral com aspectos que caracterizam a escrita. Sublinhamos, contudo, que a tradição oral não se transforma em escrita, o que ocorre é a sua transfiguração por meio da introdução de suas particularidades no texto escrito, como considera Cabaço (2004, p. 68). Sob essa perspectiva, a preocupação da nossa leitura é tentar vislumbrar, no entrecruzamento entre os procedimentos orais e escritos, as estratégias que insinuam a presença da representação do contador de histórias, uma vez que, em diferentes proporções, na produção escrita dos autores em questão, manifesta-se a consciência da importância da recuperação das nuances da oralidade, nas palavras de Padilha (1995, p. 9), como "fonte emanadora da própria identidade literária".

Nesse sentido, os textos ficcionais aqui analisados, ainda nos termos de Padilha (1995, p. 9),

1 Ana Mafalda Leite (2003, p. 94) assinala, ainda, que "[...] o conto parece ser a forma reinvindicativa cultural da oralidade e dos antecedentes da tradição narrativa moçambicana, que invade os registos genótipos da escrita romanesca" e, desse modo, nota-se que os romances de Mia Couto e Paulina Chiziane, por exemplo, são constituídos de pequenas unidades narrativas que se assemelham ao conto.

2 De acordo com Maria Teresa Salgado (2004, p. 300), praticamente todos esses autores afirmam que o universo das tradições banto influenciam suas produções literárias, isto é, não se privam de fazer uso de aspectos singulares do espaço africano. 
“contêm em seu bojo o jogo metalinguístico de desvelamento do processo de contar, o que se revela pelo procedimento narrativo do encaixe e pela representação da própria ritualidade que instaura a cena da contação de estória". Para tanto, nos apoiaremos também na constatação de Leite (2010, p. 80-81), no que diz respeito à teatralização do próprio ato narrativo, que solicita a presença da voz, efetiva nas narrativas moçambicanas, e conjuga, ao mesmo tempo, “" 'o sentido da vida' à 'moral da história', ou seja, a intencionalidade é simultaneamente pedagógica, moral e crítica, exaltante e céptica, combinando características dos modos épico e romanesco", o que situaria o romance contemporâneo moçambicano no território ambivalente do hibridismo cultural, algo que se entrelaça à construção da identidade moçambicana, vista como algo múltiplo e em transformação permanente.

Sob esse enfoque, Paulina Chiziane, contadora de histórias, como se autodenomina, por meio da escrita, busca religar-se à tradição oral e, reivindicando para si um espaço estabelecido no âmago dessa tradição, publica os romances Balada de amor ao vento (1900), Ventos do Apocalipse (1999), O sétimo juramento (2000), Niketche (2002) e O alegre canto da perdiz (2008), além dos contos de Andorinhas (2009), entre outros. No romance O sétimo juramento (2000), o aspecto que desperta interesse revela-se na resistência à eliminação do patrimônio cultural moçambicano, delineando-se a presença das crenças e dos rituais como uma espécie de aliado na preservação de um espaço ameaçado pelos novos tempos. Nessa narrativa, servindo-nos do que diz Leite (2003, p. 79), “As histórias [...] efabulam a tradição, percorrem uma temporalidade específica, uma vez que se trata da reapropriação de uma voz e conhecimento seculares, retomada e reposta em atitude griótica de pedagogia crítica.". Tendo isso em vista, convém frisar que é por intermédio da personagem Inês, um mais velho, que se configura a preocupação com o distanciamento das tradições por parte dos mais novos. Recorrendo à memória, cabe a essa avó (re)aproximar a neta Vera e o bisneto Clemente do imaginário do país, esboçando-se, por meio dessa iniciativa, uma tentativa de entrelaçar o passado e o presente.

O resultado da atitude da idosa parece surtir efeito, uma vez que, conforme Mata (2001, p. 190), “A única personagem que entende o diálogo entre as razões espirituais é Clemente, [...]. Interessante é, no capítulo XL, por isso, o diálogo entre Vera e Clemente, mãe e filho, quando este lhe comunica a sua decisão: 'servir a Deus como curandeiro"'. Como se nota, o rapaz poderia ser considerado uma personagem que, situada entre duas margens, move-se entre elas, assumindo a sua condição híbrida, pois, mesmo assimilando as características do europeu, não renuncia a suas referências próprias. Já a relação estabelecida entre Inês e Vera, embora religue esta última aos valores ancestrais, enveredase por outro caminho, como abordaremos mais adiante. É no vínculo, estabelecido entre Inês e Clemente, que o passado e o presente vão se entretecer, suscitando a ideia de que esse contato entre diferentes gerações oferece a possibilidade de um tempo pretérito ser recuperado no tempo presente, contribuindo para o seu refazimento em outra direção.

$\mathrm{Na}$ aproximação entre o mais velho e o mais novo, a avó desponta como uma contadora de histórias que, em momentos de tumulto, privilegia as narrativas da tradição oral, como se vê no capítulo VI, em que a avó intercede, no momento seguinte à possessão de Clemente, relatando quatro histórias. Na primeira, Inês começa do seguinte modo: "Era uma vez um rapazinho que pastava gado. Junto à manada, uma cobra mamba levanta a cabeça para atacar uma das vacas" (CHIZIANE, 2000, p. 26). O pretérito imperfeito corresponde a uma expressão tradicional que inicia grande parte dos contos populares, um tempo que não pertence ao tempo empírico, mas ao domínio da imaginação. Valendo-nos da explicação de Machado (2004, p. 23), 'Era uma vez' quer dizer que a singularidade do momento da narração para alguém unifica o passado mítico - fora do tempo - com o presente único - no tempo - daquela pessoa que a escuta e a presentifica. É a história dessa pessoa que se conta para ela por meio do relato universal.

E o que Inês faz é mesmo contar ao bisneto o que se passa com ele e o faz, inicialmente, por meio das narrativas, que, de certa forma, prenunciam a trajetória de Clemente. Ainda na primeira história, o protagonista mata a cobra com a mão e se torna um poderoso governador do país. A segunda, por 
sua vez, traz a aventura de um rapaz que enfrenta um leão, usando sua bicicleta como arma. Vence e mata o animal, tornando-se um rei de prestígio. Na terceira, há um jovem que descobre uma fórmula mágica e se transforma em diferentes animais, sendo considerado a encarnação do mal, enfrentando, por isso, a repressão. Enquanto na quarta história, conhecemos o relato da vida de um rei predestinado a ser líder que, após ultrapassar os obstáculos e se tornar um guerreiro, livra seu povo de 500 anos de escravidão colonial. Encerradas as histórias, porém, vó Inês é mais incisiva e explica ao neto que ele é como as personagens daquelas narrativas: um predestinado. Embora Clemente duvide, afirmando que são mitos, a avó reafirma: “- Que sejam. A vida é um mito. O mito é a vida. O que seria da vida sem o mito?" (CHIZIANE, 2000, p. 30). E o que seria deste romance sem o mito, uma vez que todo o relato é mediado pelo universo mítico, que, apesar da modernidade moçambicana procurar negar, permanece entremeado ao comportamento sociocultural do país.

A avó Inês, como representante de uma ordem ancestral e uma grande contadora de histórias, sabe aconselhar seus ouvintes. Em conformidade com Benjamin (2015, p. 167), o conselho é “[...] menos uma resposta a uma pergunta do que uma sugestão que tem a ver com a continuação de uma história que está a desenrolar-se.”. E Inês orienta o bisneto e, logo em seguida, também faz uma recomendação à neta, prevenindo-a do fato de Clemente ser um "possesso" (CHIZIANE, 2000, p. 29), mas Vera se recusa a ouvir e a aceitar. "O rosto da velha ganha uma ligeira tristeza. Sempre tenta comunicar, não encontra espaço. Os jovens dizem que as ideias dos velhos são fábulas, mitos, cantigas de embalar. A vida moderna torna as gerações incomunicáveis. A nova língua afasta as pessoas das suas origens (CHIZIANE, 2000, p. 30).

Por meio das reflexões de Inês, corrobora-se o que explica Hampatê-Bá (2010, p. 183) sobre a função dos mais velhos na tradição africana: “[...] ministram as primeiras lições da vida, não somente através da experiência, mas também por meio de histórias, fábulas, lendas, máximas, adágios, etc.”. E, embora Vera tente se opor ao ensinamento da avó, não consegue se esquivar da travessia, caracterizada também pela ambivalência e por um percurso realizado entre mundos diferentes, em que, como Clemente, conta com a ajuda dos mais velhos. Trata-se de um itinerário atribulado e alucinado, devido às consequências de um tempo de guerra, opressão e tirania. Um tempo em que a situação vivida em Moçambique é bastante delicada, pois a população, proibida de cultivar seus valores já no período colonial, e ainda depois da Independência do país, por causa do projeto nacionalista, convive com a rejeição às práticas da tradição, vistas como uma expressão de atraso, por suscitar a ideia de que o território moçambicano é um espaço primitivo.

Tanto que, em outro episódio em que Clemente tem novas visões, Vera afirma que procurará o auxílio da ciência e é questionada pela avó:

- Essa tua ciência, que resultados trouxe para o Clemente? [...] Há coisas que a ciência não explica. Há doenças que os remédios não curam. Há fenômenos da vida simplesmente inexplicáveis. Há coisas que as buscas humanas não alcançarão jamais, verdadeiros segredos dos deuses. (CHIZIANE, 2000, p. 58).

A cena é tão inapreensível que Vera precisa da avó para obter uma resposta. Inês, sabiamente, lhe diz que não há explicação para tudo, o que aponta para outra forma de aprendizagem, levando-nos, mais uma vez, às palavras de Hampatê-Bá (2010, p. 182), quando afirma que "A educação tradicional, sobretudo quando diz respeito aos conhecimentos relativos à iniciação, liga-se à experiência e se integra à vida. [...] Pois existem coisas que 'não se explicam', mas que se experimentam e se vivem.”.

Vera não tem outra opção a não ser a de percorrer um caminho incerto, obtuso, experimentando aquilo que não domina, que não tem um caráter científico. Em sua trajetória, um novo desafio: a aparição da sogra, revelando-lhe o mal espiritual que circunda a família desde tempos antigos. Com essa confissão, a sogra de Vera também se configura como aliada na trajetória da nora e do neto, visto 
que, a partir da história contada pela velha, Vera posiciona-se favoravelmente em relação ao filho e passa atuar em benefício de si e da família. Nesse trajeto, em busca de um espírito de sabedoria elevada, depara-se com outra idosa

[...] animada e [que] conta histórias dos tempos em que os animais falavam. Fala dos montes que protegem a vida e tiram a vida. Dos montes que protegem o amor e castigam o ódio [...] Clemente e Vera riem-se deliciados com a histórias. O cansaço desaparece por encanto, dando lugar à urgência de desvendar os mistérios do monte e viver as aventuras desse universo desconhecido. Vera agradece à velha e oferece todos os alimentos acabados de comprar. Oferece também o rapé. (CHIZIANE, 2000, p. 221).

A narrativa de Paulina Chiziane recupera formas tradicionais da contação de história na utilização de fábulas, provérbios, canções, lendas, contos, recriando hábitos e rituais da memória cultural de Moçambique. Distingue-se, na fala da velha contadora de histórias, no trecho citado acima, a presença da fábula, o entrecruzamento de seres inanimados e afetos, incorporando uma realidade que não pode ser explicada racionalmente e que produz o encantamento dos ouvintes, preparando-os para o percurso que ainda vão trilhar na busca do conhecimento que, mais adiante, no caso do jovem, será ressignificado, evitando a ruptura da cadeia de transmissão do patrimônio cultural moçambicano.

A caminhada para alcançar a sabedoria ancestral, transfigurada na personagem Moya, "uma alma gravitando no cosmos", situada distante no tempo, portanto, no lugar da tradição, é bastante demorada e repleta de obstáculos. Vera e Clemente ultrapassam e vencem todas as provas, uma a uma - vento, macacos, serpente, corujas, elementos que reaparecem, no final da narrativa, com outros contornos. No fim desse encontro com o sagrado, Vera vivencia uma epifania, concluindo que "Empreendeu uma viagem longa em busca de si mesma. Encontrou-se. É ela a raiz e a solução" (CHIZIANE, 2000, p. 227), ou seja, adquire consciência. Porém, recebe mais um conselho, agora, de Moya:

- Sim, empreendeste uma viagem ao passado, à busca da tua existência. Os antepassados existem para ser amados, respeitados. Protegem-nos. Mas não exageremos. A obsessão pelos mortos é característica dos que temem a luta pela vida. Não responsabilizemos os mortos pelo fracasso dos vivos. A natureza deu-nos força para conduzir a dinâmica das nossas vidas. [...] Nos antepassados devemos procurar a força e a inspiração para resistir e vencer. (CHIZIANE, 2000, p. 230).

$\mathrm{Na}$ fala de Moya, comparece um discurso que se assemelha a uma história de moral em que se destaca uma lição de vida. Vera, ao se reconectar com o passado, realiza um movimento em busca de identidade. E Moya, mesmo encenando a tradição e acentuando o valor do passado, recomenda atenção ao presente e sua advertência é ouvida e levada em consideração. Após a viagem reveladora, a mudança de atitude de Vera é um indicativo de que ela teria alcançado certo entendimento, adquirido certa percepção do que ocorre ao seu redor, visto que passa a escutar também o que a avó Inês tem a contar sobre Clemente:

Vera recorda o passado da família da avó Inês. Gente morrendo no mar. Desaparecendo no mar. Gente com espíritos no mar. Gente que afirma ter vivido muitos anos no fundo do mar. As palavras da velha são delírios mas podem ser profecia.

A velha fala dos segredos do mar. Ensina as palavras mágicas para invocar os deuses do mar. Conta todas as histórias sobre a vida no fundo do mar." (CHIZIANE, 2000, p. 251252)

Em um recuo ao passado, Vera relembra histórias familiares ao ouvir o relato da avó, deixandose penetrar pelo inexplicável, pelo enigmático. São histórias extraordinárias, no entanto, Inês é 
uma personagem de quem se precisa desconfiar, visto que, por meio de suas narrativas fantasiosas, atravessadas por mistérios insondáveis e palavras mágicas, encantadoras, mais uma vez, propaga seu conhecimento e sua sabedoria. Sendo assim, exerce novamente sua função de contadora de histórias ao se dispor a transmitir, de modo metafórico, a memória cultural de sua gente. E, sinalizando o fluxo da vida por intermédio da imagem da água, enxerga Clemente como seu sucessor, com condições de perpetuar o legado deixado por ela.

Voltando à trajetória de Clemente, observa-se que, de acordo com Hampatê-Bá (2010, p. 184), o ritual de iniciação faz o iniciado descobrir sua própria relação com o mundo das forças e aos poucos o conduz ao autodomínio, cuja finalidade é transformá-lo em um "homem completo e guardião do mundo vivo". Em determinado momento de seu percurso, Clemente decide ser curandeiro. Essa decisão, se, por um lado, demonstra que o aprendizado foi alcançado por meio das histórias e da sabedoria dos mais velhos que o convertem em um transmissor da herança cultural moçambicana, por outro, indicia uma subversão à hierarquia que constitui a tradição, uma vez que a função de curandeiro é exercida, de um modo geral, por aqueles que têm um saber construído por um acúmulo de conhecimento e experiência.

Além disso, na escolha do rapaz, delineia-se uma transgressão aos padrões impostos pela modernidade: "Ser curandeiro é despretigiante nas nossas mentes alienadas. É invocar conhecimentos e tradições que se pretendem banidas desde os tempos da inquisição europeia. É resgatar o ser e o saber de um povo desprezado" (CHIZIANE, 2000, p. 243). Clemente, ao se posicionar contra o silenciamento da tradição, incorpora a responsabilidade de levar adiante o saber que lhe foi passado, renovando-o.

Lembramos ainda que, nas sociedades africanas tradicionais, como explicam Serrano e Waldman (2008, p. 130), a "consciência de pertencimento" a determinada família amplia-se a partir da realização de rituais de iniciação que acontecem desde muito cedo. E, a princípio, Clemente, embora tenha visões, não demonstra ter essa "consciência de pertencimento", o que o obriga a trilhar uma trajetória complexa, repleta de ambivalências, na tentativa de adquiri-la. No início desse percurso, contudo, Clemente conta com o auxílio da avó Inês que, por meio das histórias, aos poucos, vai reaproximando o neto de suas origens a fim de que ele adquira o saber necessário para garantir a sobrevivência familiar. E a demanda para a aquisição desse conhecimento é permeada por provas que desafiam o seu entendimento e o colocam em situações que exigem dele muita perspicácia. Clemente realiza, portanto, uma viagem cujo itinerário torna-se muito semelhante a um ritual de passagem, pois, ao longo do trajeto, vai sofrendo mudanças.

Clemente, aos poucos, vai absorvendo as histórias, os segredos, os mistérios que o circundam e conquistando a consciência da missão que lhe foi delegada. É um processo dinâmico, afinal, trata-se de algo movente, uma vez que o ocorre entre os mais velhos e Clemente, expressando-se como um fluxo de saber que, além de não poder ser interrompido, exige ainda que o jovem, sem deixar de ser quem é, modifique-se. Surgem, em vista disso, situações demasiadamente inusitadas que desafiam a sua competência para compreender. Em seu processo de aprendizagem, Clemente prova alguns embates em que se insinua a sua metamorfose. O olhar do rapaz modifica-se e o indicativo de seu crescimento é a sua atitude corajosa e decidida diante do pai. Autêntico membro da família, torna-se, finalmente, consciente do significado que essa família representa. E, empenhado em absorver os ensinamentos da avó e dos guias espirituais, preservando a sua família que, de certo modo, está associada à ideia de nação, caminha à procura de um passado identitário que só pode ser recuperado pelos trilhos da identidade plural, que estaria no encontro de um caminho entre a tradição e a modernidade.

Nessa trajetória entre a tradição e a modernidade, insere-se também, de outra maneira, a escrita de Lilía Momplé, cuja influência literária está muito relacionada à sua infância, mais especificamente às histórias narradas pela avó, que era macua e contava, com frequência, "estórias lindas da tradição 
em volta da fogueira" (QUIVE, 2012). ${ }^{3}$ Almejando escrever, um dia, aquelas estórias, seu primeiro livro, uma coletânea de contos intitulada Ninguém matou Suhura, é publicado em 1988, com o subtítulo "Estórias que ilustram a História", cujas narrativas datam de 1935 a 1974. Em seguida, vem a público o romance Neighbours, de 1995, e os contos d'Os olhos da cobra verde, de 1997. Neste último livro, os rituais da tradição macua comparecem com maior frequência e, no conto "Xirove", acompanhamos os preparativos para o ritual do Xirove, um processo de purificação que visa reintegrar alguém que cometeu uma grave infração à comunidade.

Sob essa perspectiva, não por acaso, em mais um romance contemporâneo moçambicano, também se distingue a confluência de aspectos da cultura oral com a escrita, fazendo-se presente a força das tradições. Nesse sentido, Neighbours é bastante significativo, visto que a autora, como destaca Cury (2010, p. 216), “[...] faz questão de explicitar que muitas de suas narrativas partem de acontecimentos resgatados à sofrida memória coletiva de Moçambique.”. E, nessa obra, mais especificamente, na máxima da epígrafe, aborda-se a problemática da alienação: "Quem não sabe de onde veio não sabe onde está nem para onde vai." (MOMPLÉ, 2004). No processo de alienação da memória, que pode ser entendido como perda do domínio sobre aquilo que somos e produzimos, tanto no que se refere ao lugar do qual fazemos parte quanto no que diz respeito ao corpo social historicamente situado e definido de onde viemos, o sujeito experimenta a despersonalização e a letargia. Isso também se sucede com Moçambique, que, ao evoluir para a forma de nação, vê as suas referências espaçotemporais transmutarem-se, como resultado do avanço das forças econômicas e ideológicas da sociedade moderna.

Nesse contexto, a alienação das personagens, entre eles, Dupont, Zalíua e Romu, poderia ser associada ao que, segundo Tutikian (2006, p. 60), experimenta Moçambique, uma nação que se entregou ao alheamento em consequência dos expedientes determinados pelas guerras colonial e civil. Alheamento que tem tanto poder, tanta eficácia, que leva os próprios moçambicanos, despojados ou desconectados de suas lembranças, a promoverem ações contra eles próprios. Contrapondo-se a essas personagens, deparamo-nos com Januário, cuja história de vida se apoia em um passado que, conforme Salgado (2011, p. 177), o "[...] salvou da raiva e do recalque do passado pela ligação com a sua origem, com a sua terra, o que o levou a engajar-se na reconstrução de Moçambique." Acompanhando a trajetória das personagens masculinas, em Neighbours, constata-se, por meio da maneira como o percurso de cada um vai sendo revelado, que Lília Momplé demonstra certo cuidado em orientar o leitor para que ele compreenda a narrativa, mas não o subestima, o que, nos termos de Salgado, é um aspecto do romance que se aproxima de "[...] uma das características fundamentais da tradição oral africana: o seu valor pedagógico, a sua preocupação em levar o ouvinte ou o leitor da narrativa a refletir sobre o narrado, ao mesmo tempo em que lhe são dadas pistas e chaves de leitura." (SALGADO, 2011, p. 174).

Refletir sobre o narrado é também refletir sobre as personagens, o que nos instiga a mencionar a instância que nos conduz nessa jornada, o narrador em terceira pessoa, que não se trata, porém, de uma voz hegemônica ou centralizadora, uma vez que a recorrência ao discurso indireto livre em várias situações minimiza a voz em terceira pessoa, dando lugar a "voz" de diferentes personagens. Como é possível constatar, as memórias e experiências das personagens, aliadas ou não à figura desse narrador em terceira pessoa, movimentam intensamente a narrativa, que ora elege os segmentos do enredo reveladores da motivação interior das personagens, dando preferência à cena pormenorizada, em que o tempo do discurso torna-se maior que o tempo da história, utilizando-se ainda das interrupções na sequência narrativa que acentuam essa dilatação temporal, ora dá preferência à diminuição do tempo do discurso, que promove a abreviação dos acontecimentos ao se mostrar menor do que o tempo da história.

3 Lília Momplé em entrevista para Eduardo Quive (2012). 
Observa-se, assim, que o deslocamento de um momento para o outro é contínuo e essa maneira de narrar dá a impressão de que os acontecimentos duram muito mais do que aparentam, sensação que não se desfaz nem mesmo pela marcação cronológica da duração de algumas horas da noite, conforme indiciado na sequência dos capítulos, 19h, 21h, 23h, 1h, 8h. E o que corrobora essa ideia de dilatação do tempo cronológico são as interrupções na sequência narrativa, permitindo o acréscimo de pequenas histórias, que vão sendo agregadas à história mais extensa. Ao imprimir velocidade mais lenta ao relato, tem-se a possibilidade de explorar os acontecimentos que se passaram e se passam no interior do país, proporcionando uma visualização ampla do espaço da narrativa.

Na manifestação dessa artimanha da narração, constata-se, também, um registro pormenorizado de elementos que despontam em toda a extensão do romance e, nesse sentido, o narrador insinua aspectos muito semelhantes ao do contador de história, que em seus relatos não abre mão dos detalhes que, nas palavras de Hampatê-Bá (2010, p. 208), “[...] animam a narrativa, contribuindo para dar vida à cena". Os detalhes possuem importância para a verdade do conjunto e o contador, se não faz o relato em sua integridade, não o faz de modo algum. Nesse caso, é sugestivo o fato de a narrativa estar organizada em torno de três histórias, narradas alternadamente, em um movimento que conduz o leitor por trilhas que intensificam o mistério em torno da trama, o que nos parece uma maneira de contar que também está relacionada a uma estratégia característica do contador de história: chamar a atenção do ouvinte, no caso, do leitor, despertando sua curiosidade, instigando-o a acompanhá-lo em sua história até o final.

E mais um artifício da narração nos remete a uma peculiaridade do contar histórias: o acréscimo de acontecimentos em um encadeamento que se estende bastante, promovendo, por exemplo, a interpenetração de uma história na outra, de modo que as partes, as histórias menores, como peças de um mosaico, se agregam para a formação do todo, o enredo, também ele fracionado por causa desses vários pedaços de histórias que vão se somando, além de diferentes formas narrativas e subgêneros, que caminham desde o conto de fadas até nuances do romance policial.

Sendo assim, em Neighbours, defrontamo-nos com uma narrativa que contém uma história, a que conta a violência de uma ação terrorista, em que são inseridos, além de cinco marcações temporais (19 horas, 21 horas, 23 horas, 1 hora e 8 horas), três espaços simultâneos, respectivamente, a casa de Narguiss, a de Leia e Januário, e a de Mena e Dupont, que, de diferentes maneiras, remetem à trama do crime. A história matriz desdobra-se nas três histórias menores que a preenchem. No interior dos três espaços há também a narração de trechos de história da trajetória das personagens que, convém ressaltar, não se misturam, isto é, o narrador desloca-se de um espaço ao outro, sem entrecruzálos. Inclusive, na última marcação temporal, cujo subtítulo é "Os mortos e os vivos", e não mais a referência às três moradias, o narrador descreve o que se passa em cada residência, sem aproximá-las mais uma vez.

As histórias encaixadas que preenchem a história matriz, conforme registrado acima, aproximamse das "mise em abyme" que podem ser vistas, segundo Dällenbach (1979, p. 58), como "[...] microcosmos da ficção, [que] impõem-se, semanticamente, ao macro-cosmo que as contém, ultrapassandono e, duma certa maneira, acabam por englobá-lo." Parece-nos que em Neighbours esse processo é intenso, visto que são os eventos que se dão no interior das três residências que compõem, juntos, o romance. Na primeira das moradias, a casa de Narguiss, às 19 horas, prepara-se o Ide, cerimônia que comemora o fim do Ramadã, o mês sagrado durante o qual os muçulmanos realizam o ritual do jejum. Trata-se de um mês de renúncia, em que se exercita a paciência, o autocontrole, a humildade, a alteridade, recordando-se daqueles mais necessitados. Prepara-se, portanto, uma confraternização em que se festeja a resistência às dificuldades.

Há, no entanto, um mal-estar instaurado pela ausência da lua naquela noite, algo incomum para a realização do Ide, o que indicia uma atmosfera de tensão, intensificada pelo fato de a família ter 
tanta comida, tanta fartura, enquanto, na casa de Leia e Januário, vizinhos de Narguiss, a pobreza se evidenciar no prato repetido, diariamente, pelo casal. Casal que, mesmo enfrentando muitas vicissitudes, reconhece-se privilegiado por ter um lugar digno para habitar, condição rara naqueles tempos vividos em Maputo. Nessa casa, ainda, vive Íris, a filha de dois anos do casal. Distante da casa de Narguiss e de Leia e Januário, está a casa de Mena e Dupont, um mauriciano que trama, com outros homens, a ação criminosa focalizada pelo romance.

No que diz respeito às histórias dentro das histórias, na marcação temporal das 21 horas, em casa de Narguiss, desponta a trajetória de Fauzia (prima de Muntaz, Rábia e Dinazarde, as filhas da protagonista), que pretende se mudar para Portugal, onde uma parte da família vive de negócios obscuros. Aqui, destaca-se a alienação de Fauzia e também da própria Narguiss; ambas negam a percepção da realidade que as circunda, inclusive, a que se passa no país europeu. Em casa de Leia e Januário, por sua vez, contrastando com o que se sabe da casa vizinha, o narrador detém-se no passado do rapaz, que veio de uma aldeia entre as florestas do Alto Molòcuê, e, hoje, é professor consciente do seu valor e de sua profissão:

Desde muito pequeno que Januário também se apercebeu da extrema pobreza da gente da aldeia, e, particularmente, da sua própria família, cujo trabalho árduo no campo parecia gerar apenas carências. O pai era um homem que, já na altura em que Januário nasceu, parecia viver numa permanente despedida desse mundo. Grande respeitador dos antepassados, tinha como principal ocupação o cumprimento escrupuloso do culto dos mortos e a miséria não lhe causava muito sofrimento. (MOMPLÉ, 2004, p. 47-48).

Embora afastado geograficamente de seu lugar de origem, Januário não se distancia de sua cultura, não se descaracteriza, permanece, por meio das lembranças, ligado ao seu espaço de pertencimento. Distinguindo-se da trajetória de Januário, apresenta-se o percurso de Dupont, Zalíua e Romu, relatado pelo narrador quando, às 21 horas, desloca sua perspectiva de visão para a casa de Leia e Dupont. Nesse fragmento, no interior da marcação espaço-temporal, há uma divisão ainda quanto à trajetória dessas três personagens. Há um subitem, intitulado Dupont, outro nomeado Zalíua e, por fim, mais um denominado Romu. Todos são narrados em terceira pessoa a partir do olhar observador de Mena.

À medida em que o narrador apresenta, em fios separados, a história desses três homens, confirmamos que a ausência de memória ou a negação das raízes culturais é um dos maiores responsáveis pelas circunstâncias que os conduzem à vida corrupta e criminosa. Dupont, Zalíua e Romu têm uma visão unilateral, homogênea, parcial da realidade e o que chama a atenção nas três histórias é, sobretudo, o final, que tem praticamente a mesma estrutura:

Mas agora, Mena, sentada no banco da cozinha, por mais que se interrogue, jamais saberá que o que levou Dupont a tornar-se cúmplice dos outros dois foi a ganância por dinheiro. (MOMPLÉ, 2004, p. 73).

Mas agora, Mena, sentada no banco da cozinha, por mais que se interrogue, jamais saberá que o que levou Zalíua a tornar-se cúmplice dos outros dois foi a voraz sede de vingança. (MOMPLÉ, 2004, p. 87).

Mas agora, Mena, sentada no banco da cozinha, por mais que se interrogue, jamais saberá que o que levou Romu a tornar-se cúmplice dos outros dois foi o ódio desvairado à sua própria raça. (MOMPLÉ, 2004, p. 99).

O narrador, ao explorar o mesmo motivo no final de cada história, finalizando-as de forma análoga e explícita, mobiliza a tradição popular, tendo em vista que o discurso oral, como assinala Lopes (2001, p. 212), tem na repetição um de seus aspectos mais característicos, colaborando, principalmente, no 
processo de preservação da memória do ouvinte. Além disso, essa tríade de motivações - ganância, vingança, ódio - sugere uma espécie de escala da alienação das personagens no contexto históricosocial do país, culminando com a negação da própria origem. Dupont, Romu e Zalíua assimilam o papel do branco opressor, rivalizando com aqueles considerados inferiores. Descaracterizando-se, essas três personagens sofrem um processo de despersonalização e descarregam o ressentimento e despeito na violência contra os mais fracos.

Às 23 horas, também ocorre a introdução de um fato que merece destaque e que, em certas proporções, é recorrente tanto na casa de Narguiss quanto na de Leia e Januário. Na primeira moradia, Muntaz, a filha mais nova e consciente de Narguiss, ouve no noticiário o relato de um massacre no interior de um ônibus, enquanto as outras pedem para que ela desligue a televisão: "Muntaz não consegue habituar-se à rotina das matanças e massacres e não pode deixar de admirar-se com a boa disposição das irmãs e de Fauzia" (MOMPLÉ, 2004, p. 104). Mais uma vez, com exceção de Muntaz, não se evidencia a preocupação das outras mulheres em acessar a violência que predomina no país, preferindo-se o afastamento, provocador da alienação das personagens que, enquanto devaneiam, não precisam encarar as perdas. Aqui, vale salientar a relação de Muntaz com as duas irmãs, vista como algo que, nos termos de Salgado,

[...] reencena até a clássica rivalidade das irmãs dos contos de fadas, uma vez que Muntaz assume um comportamento crítico e sensível, em contraste com Dinazarde e Rábia, que se irritam com a mais nova, pois acreditam que as mulheres devem se envolver apenas em seus assuntos pessoais. Mas é justamente o temperamento crítico e irônico em relação à realidade que a cerca que acaba por distinguir Muntaz das heroínas dos contos de fadas. (SALGADO, 2011, p.179).

Nota-se, portanto, a inserção de uma história, que nos remete ao conto de fadas, no interior da narrativa da família de Narguiss. Aliás, Salgado também menciona que Muntaz, apesar de ser um nome usual entre os indianos, remete-nos à Muntaz-Mahal, a "joia do palácio", décima quinta esposa do imperador Shah Jhahan, que, depois da morte de sua amada, a fim de exaltar a sua memória, construiu o Taj-Mahal. Muntaz-Mahal era uma princesa voltada à caridade e à bondade, dedicada à ações em benefício dos oprimidos. Nesse sentido, poderíamos aproximar a personagem do romance à princesa da história popular indiana.

Muntaz também é responsável pela manutenção da tradição, como se vê no episódio inserido na última marcação temporal do romance, às 8 horas, em que providencia os cuidados em torno do corpo da mãe assassinada pelos terroristas:

[...] para que o corpo regresse a casa ainda esta manhã pois, só em casa, poderá ser tratado de acordo com os rituais de morte da religião maometana. Hão de vir então as experientes mulheres que darão banho ao corpo de Narguiss, lhe espremerão as vísceras até que a água das lavagens saia límpida, livre de qualquer impureza e, finalmente, o envolverão no imaculado pano branco que lhe servirá de mortalha. (MOMPLÉ, 2004, p. 149).

Nessa citação revela-se a circularidade da história que se passa "Em casa de Narguiss", onde, às 19 horas, há um ritual em que as mulheres mais jovens, em companhia da mãe, a mais velha, preparam os alimentos que compõem a festa que celebra o fim do Ramadã. No final, às 8 horas, no mesmo local, Muntaz, a mais jovem da casa, guardiã da herança cultural deixada pela mãe, exige a realização de outro rito de passagem que, entretanto, marca o final da vida de Narguiss. Nesse momento, o conjunto de mulheres mais velhas da comunidade muçulmana é chamado a participar dos preparativos da cerimônia e depreendemos, dessa atitude, utilizando-nos das palavras de Serrano e Waldam (2008, p. 137), que "[...] a vida do indivíduo é percebida como participativa, ou seja, imersa na coletividade. Essa postura engendra a consciência de pertencimento [...]”, consciência mais uma vez evidenciada 
por Muntaz.

$\mathrm{Na}$ casa ao lado, às 23 horas, Leia também tem o sono perturbado pela mesma notícia da chacina, no entanto, ao contrário do que se passa com as vizinhas, a consciência da tragédia experimentada por Moçambique é compartilhada com Januário. O narrador focaliza o comportamento de Íris, a filha pequena do casal, e o incômodo da criança, que apenas chora, sem trégua e sem aparentar nenhuma espécie de enfermidade ou necessidade, insinua a introdução de mais uma história no interior da história da família: a do mito de Íris, a deusa mensageira. A fala do pai corrobora essa impressão: “-Quem sabe se está a adivinhar desgraça!” - graceja Januário.” (MOMPLÉ, 2004, p. 115). Íris, que esfrega os olhos com insistência, sugere pressentir o que ocorrerá logo mais em sua casa, tentando, talvez, avisar os pais de que a tragédia também chegará ali.

Há, finalmente, mais uma perspectiva de se pensar as histórias encaixadas no romance de Lília Momplé no que concerne à presença de um subgênero no interior do gênero romanesco, uma vez que o romance apresenta traços da narrativa policial ao levar o leitor a juntar pistas, diante de cenários instigantes, para desvendar o crime hediondo praticado contra Leia, Januário e Narguiss, envolto em uma série de detalhes surpreendentes. Depreende-se, assim, que a recorrência à técnica das histórias encaixadas acentua a presença do passado colonial ainda no presente pós-independência, indiciando que, apesar de Moçambique não estar mais sob o domínio português, outras formas de ameaça persistem.

Por fim, convém ressaltar que este trabalho, ao aproximar romances de diferentes autores, procurou mostrar que a articulação entre elementos que indicam a representação do contador de histórias na ficção contemporânea de Moçambique assegura a inesgotável relação com o já vivido. Além disso, o "contar histórias" leva-nos para muitas veredas da interioridade do país, uma interioridade complexa e múltipla. Ao atentarmos para os deslocamentos que comparecem nos dois romances abordados aqui, constatamos que não ocorre o predomínio da diáspora, ao contrário, prevalecem os trânsitos que acontecem dentro de Moçambique.

Trânsitos que se manifestam também em termos dos recursos empregados, entre eles, sobressaem a congeminação instalada no relacionamento dos mais jovens com os mais velhos, em que conhecimentos e experiências se hibridizam; as histórias dentro das histórias, e a presença de narradores que contém aspectos que, muitas vezes, resvalam nos traços que constituem o contador de histórias. Em outras palavras, acompanhamos as personagens, os narradores e a forma compósita dos enredos, que se constituem de várias histórias encaixadas, provocando um movimento plural, pluralidade que se infiltra no contar histórias, que desloca o leitor para universos outros, possibilitando que ele se embrenhe no caráter híbrido que fundamenta esses romances, em que o contador de histórias, que se inscreve nas narrativas, estabeleça, com o narrador romanesco, um outro híbrido.

Porém, o que nos instigou em nosso percurso foi a tentativa de compreensão da finalidade da representação do contador de histórias nesses romances moçambicanos. E, apesar de nosso trabalho se encerrar com mais indagações do que respostas, acreditamos que uma das funcionalidades seja a reinvenção da tradição, propiciadora da incorporação do saber popular, quase sempre oral, encoberto pela legitimidade que a palavra escrita possui no mundo ocidental. Saber, vale sublinhar, atemporal, que se manifesta, de um modo geral, por meio dos mitos e dos rituais, promovendo a recuperação de fragmentos da História, guardados no inconsciente de uma comunidade e, provavelmente, impossível de serem retomados de outra maneira. Há, ainda, outro propósito na representação do contador de histórias: além de problematizar a racionalidade do colonizador, imprime o referencial mítico do colonizado, descrito, desse modo, a partir do ponto de vista endógeno, a partir do interior de Moçambique, contribuindo para a constituição de uma narrativa que situa entre fronteiras tênues. 


\section{Referências}

BENJAMIN, Walter. O contador de história. Considerações sobre a obra de Nikolai Leskov. In: Magia e técnica, arte e política: ensaios sobre literatura e história da cultura. Tradução de João Barrento. Porto: Assírio e Alvim, 2015. p. 145-178.

CABAÇO, José Luís. A questão da diferença na literatura moçambicana. Via Atlântica. São Paulo, n.7,p. 61-69, out. 2004..

CABAÇO, José Luís. Moçambique: identidade, colonialismo e libertação. São Paulo: Editora UNESP, 2009.

CHABAL, Patrick. Vozes moçambicanas: literatura e nacionalidade. Lisboa: Vega, 1994.

CHIZIANE, Paulina. O sétimo juramento. Lisboa: Caminho, 2000.

CURY, Maria Z. F. Lília Momplé: narrativa em letras minúsculas. In: SECCO, Carmen T. et al. África \& Brasil: letras em laços II. São Caetano do Sul, São Paulo: Yendis Editora, 2010. p. 213-225.

DÄLLENBACH, Lucien. Intertexto e autotexto. Coimbra: Poétique, n. 26, 1979. p. 51-67.

HAMPATÉ BÂ, Amadou. A tradição viva. KI-ZERBO, Joseph (Org.). In: História Geral da África, vol. 1 - Metodologia e pré-história da África. Brasília: UNESCO, 2010. p. 168-212.

LARANJEIRA, Pires. Literaturas Africanas de Expressão Portuguesa. Lisboa: Universidade Aberta, 1995.

LEITE, Ana Mafalda. Formas e lugares fantasmas da memória colonial e pós-colonial. Via Atlântica, São Paulo, n. 17, p. 69-82, jun. 2010.

LOPES, José de Souza M. Cultura acústica e memória em Moçambique: as marcas indeléveis numa antropologia dos sentidos. Scripta, Belo Horizonte, v. 4, n. 8, $1^{\circ}$ sem. 2001. p. 208-228.

MACHADO, Regina. Acordais: fundamentos teórico-poéticos da arte de contar histórias. São Paulo: Difusão Cultural do Livro, 2004.

MATA, Inocência. A condição pós-colonial das literaturas africanas de Língua Portuguesa: algumas diferenças e convergências e muitos lugares-comuns. LEÃO, A. V. (Org.). In: Contatos e ressonâncias: literaturas africanas de Língua Portuguesa. Belo Horizonte: PUC Minas, 2003. p. 43-72.

MATA, Inocência. O sétimo juramento, de Paulina Chiziane: uma alegoria sobre o preço do poder. Scripta, Belo Horizonte, v. 4, n. 8, p. 187-191, $1^{\circ}$ sem. 2001.

MOMPLÉ, Lília. Neighbours. Porto: Editora Porto, 2004.

PADILHA, Laura Cavalcante. Entre a voz e a letra: o lugar da ancestralidade na ficção angolana do século XX. Niterói: Eduff, 1995.

QUIVE, Eduardo. Entrevista a Lília Momplé. Revista de Literatura Moçambicana e Lusófona - Literatas, Maputo, n. 43, ano II, ago. 2012. p. 9-13.

SALGADO, Maria Teresa. Neighbours: de violências, mulheres, mudanças...e homens. Diadorim, Rio de Janeiro, v. 9, p. 173-182, jul. 2011.

SALGADO, Maria Teresa. Um olhar em direção à narrativa contemporânea moçambicana. Revista Scripta. Belo Horizonte: PUC-MG, v. 8, n. 15, p. 297-308, $2^{\circ}$ sem. 2004.

SERRANO, Carlos; WALDMAN, Maurício. Memória d'África: a temática africana em sala de aula. São Paulo: Cortez, 2008.

TUTIKIAN, Jane. Velhas identidades novas: o pós-colonialismo e a emergência das nações de Língua Portuguesa. Porto Alegre: Sagra Luzzatto, 2006. 